\begin{tabular}{lrr}
\hline Volume 21 & Nomor 1, Januari 2020 & Halaman 31-39 \\
URL: https://jurnal.unej.ac.id/index.php/SEMIOTIKA/index & E-ISSN: 2599-3429 & P-ISSN: 1411-5948 \\
\hline
\end{tabular}

\title{
PEMEROLEHAN BAHASA KEDUA PADA ANAK BERKEBANGSAAN SOMALIA DI TANGERANG SELATAN
}

\section{SECOND LANGUAGE ACQUISITION OF A SOMALIAN KID IN SOUTH TANGERANG}

\author{
Dedy Eko Aryanto ${ }^{1 *}$ \\ ${ }^{1}$ Fakultas Ilmu Tarbiyah dan Keguruan UIN Syarif Hidayatullah, Jakarta \\ *Corresponding Author: ekoaryanto17@gmail.com \\ Informasi Artikel:
}

Dikirim: 15/1/2020; Direvisi: 20/1/2020; Diterima: 27/1/2020

\begin{abstract}
Ahmad, a four-year 8-month-old Somali child who lives in South Tangerang, communicates in an English speaking family, occasionally his mother communicates using Indonesian. Ahmad is unique in speaking both languages. He can speak English fluently and speak Indonesian mixed with English fluently too. The purpose of this study is to determine the second language acquisition system and forms of second language understanding for Ahmad, both in the structure of question sentences and answer sentences. The research data is in the form of language. There are words and sentences that Ahmad used when having a dialogue with the researcher and his mother. Information is collected using "Simak Libat Cakap" (involved conversation observation technique) and listening method with note-taking design and the interview to Ahmad's parents. The classified data were analyzed using descriptive-analytical methods. The results show that Ahmad is a Somali child who speaks English as a mother tongue, and Indonesian as his second language caused by family environmental factors and his mother's laundry workplace, playmates, and social media youtube and television when watching a film with his mother. Ahmad can speak Indonesian mixed with English by having the right grammatical meaning and understanding and answering the researchers' questions and his mother's questions using Indonesian. Phonologically, Ahmat cannot pronounce the sound $/ r /$ and sound $/ \mathrm{s} /$. He pronounces the sound $/ r /$ always with the sound $/ / /$, and sound $/ s /$ it is always replaced by the sound /c/.
\end{abstract}

Keywords: language acquisition, second language, Somali children.

\begin{abstract}
Abstrak
Ahmad, anak Somalia berusia 4 tahun 8 bulan, yang hidup di Tangerang Selatan, berkomunikasi dalam keluarga berbahasa Inggris, sesekali ibunya dalam berkomunikasi menggunakan bahasa Indonesia. Ahmad memiliki keunikan dalam berbahasa bahasa kedua, yakni mampu berbahasa Inggris dengan lancar dan berbahasa Indonesia bercampur bahasa Inggris dengan lancar juga. Tujuan riset ini untuk mendeskripsikan sistem pemerolehan bahasa kedua dan bentuk-bentuk pemahaman bahasa kedua bagi Ahmad, baik dalam bentuk kalimat tanya maupun kalimat jawaban. Data riset ini berupa bahasa, yang di dalamnya terdapat kata-kata dan kalimat yang digunakan Ahmad ketika dilakukan dialog dengan peneliti dan ibunya. Dalam pengumpulan data dilakukan dengan menggunakan metode simak libat cakap dengan teknik catat dan metode cakap dengan kedua orang tua Ahmad. Data yang telah diklasifikasi dianalisis dengan metode deskriptif analitis. Hasil penelitian menunjukkan bahwa Ahmad merupakan anak warga Somalia yang berbahasa ibu bahasa Inggris, dalam pemerolehan bahasa kedua, yakni bahasa
\end{abstract}


Indonesia karena faktor lingkungan keluarga, lingkungan tempat kerja ibunya sebagai kerja cuci, lingkungan bermain teman sebayanya, dan karena media sosial youtube dan televisi ketika menonton film bersama ibunya. Ahmad dapat berbahasa Indonesia yang dicampur dengan bahasa Inggris dengan memenuhi makna gramatikalnya, dan mampu memahami serta menjawab pertanyaan peneliti dan pertanyaan ibunya dengan menggunakan bahasa Indonesia. Secara fonologis, Ahmat belum bisa melafalkan bunyi /r/ dan bunyi /s/. Dalam pelafalan bunyi /r/ selalu diucapkan atau dengan bunyi /l/, dan dalam pengucapan bunyi /s/ selalu diganti dengan bunyi /c/.

Kata kunci: akuisisi bahasa, bahasa kedua, anak Somalia.

\section{PENDAHULUAN}

Bahasa merupakan kebutuhan penting dalam kegiatan berinteraksi dan berkomunikasi sehari-hari. Bahasa bukan hanya sebagai alat untuk melakukan komunikasi, melainkan bahasa juga berlaku sebagai alat berpikir. Hal tersebut terjadi karena manusia akan merumuskan suatu hal sesuai dengan hal yang dipikirkannya yang bertujuan untuk menghasilkan sebuah komunikasi yang baik.

Definisi yang telah dikemukakan oleh Berger dan Chaffe (1987) cukup memadai dalam menerangkan sebuah konsep tentang komunikasi, bahkan termasuk merengakan sebuah produksi, pemprosesan efek atau suatu signal dalam komunikasi antarpribadi, organisasi komunikasi, komunikasi kelompok, komunikasi massa, komunikasi politik, komunikasi pendidikan, komunikasi penyuluhan, komunikasi pembangunan dan komunikasi yang lainnya. Ilmu komunikasi pada dasarnya merupakan pengetahuan tentang peristiwa komunikasi yang diperoleh melalui penelitian tentang sistem, proses, dan pengaruhnya yang dilakukan secara rasional dan sistematik, serta kebenarannya dapat diuji dan digeneralisasikan. Dalam komunikasi sehari-hari yang dilakukan manusian selalu melibatkan bahasa, yang dikategorikan sebagai komunikasi verbal.

Pemerolehan bahasa, atau biasa diesbut dengan istilah language acquistion merupakan sebuah proses manusia dalam mendapatkkan kemampuan menangakan, menghasilkan dan menggunakan sebuah kata untuk pemahaman mereka dan bentuk komunikasi mereka. Kapasitas ini melibatkan berbagai macam kemampuan linguistik, baik dari kemampuan sintaksis, kemampuan fonetik dan kemampuan kosakata yang sangat luas. Bahasa yang diperoleh dapat berupa vokal yang sama halnya pada bahasa lisan atau bahasa isyarat yang merupakan bahasa manual.

Kategori pemerolehan bahasa dibagi menjadi dua yaitu pemerolehan bahasa pertama dan pemerolehan bahasa kedua. Bahasa ibu atau biasa dikenal sebagai bahasa pertama. Dalam pemerolehan bahasa pertama, hal tersebut diperoleh pertama kali meniru bahasa yang terdapat dalam keluarganya, pada proses ini anak tidak akan sadar dalam pemerolehan bahasa pertamanya dan tanpa sadar bahwa dia sedang mempelajari bahasanya. Setelah menguasai bahasa pertama seseorang pasti akan memerlukan komunikasi secara luas, ke dunia yang lebih luas guna mengembangkan kemampuannya dan kehidupannya. Oleh karena itu, seseorang akan berusaha belajar untuk mendapatkan bahasa kedua. Bahasa kedua diperoleh dipelajari oleh seseorang dalam keadaan sadar, sedangkan pemerolehan bahasa pertama diperoleh 
dengan tidak sadar dari kesehariannya. Pemerolehan bahasa kedua bagi anak diperoleh dengan pemahaman belajar dengan sadar.

Terdapat dua cara pemerolehan bahasa kedua bagi seseorang untuk mendapatkan bahasa kedunya (Nurhadi dan Roekhan, 1990:108). Pertama, dengan cara belajar secara langsung dan informal seperti anak kecil yang mempelajari bahasa ibunya. Kedua, belajar bahasa kedua berlangsung secara formal dalam pembelajarannya di suatu instusi dan menyangkut kaidah tata bahasa. Cara yang pertama tersebut dinamakan " pemerolehan" (acquisition) dan yang kedua itu dinamakan sebuah pemebelajaran "learning".

Psikolinguistik lahir sejak tahun 1952 dan ilmu ini digunakan pada tahun 1954, dua tahun setelah ilmu psikolinguistik ini lahir, dan ilmu ini digunakan oleh Charles E Osgood dan Thomas A. Ilmu ini merupakan ilmu yang di dalamnya mempelajari sebuah perilaku berbahasa manusia, baik perilaku yang tampak ataupun perilaku yang tidak tampak ini dipelajari dalam psikolinguistik (Natsir, 2017). Darjowidjojo (2003) menyatakan secara rinci bahwa ilmu psikolinguistik mempelajari empat topik utama. Yang pertama mempelajari komprehensi, yang kedua meneganai produksi, dan yang ketiga mengenai landasan biologis serta neurologis, dan yang keempat ini membahas mengenai pemerolehan bahasa. Dalam pemerolehan bahasa terdapat beberapa teori, yakni behaviorisme, mentalisme, dan kognitivisme.

Teori behaviorisme merupakan sebuah teori yang menyatakan bahwa semua perilaku dan tindak berbahasa yang telah ditimbulkan karena adanya sebuah rangsangan yang lebih dahulu atau biasa disebut dengan stimulus dan jika rangsangan ini diamati dan diketahui tindak balas atau respon dan hal itu dapat diprediksi (Oktavia dan Abdullah, 2017).

Nuryani dan Dona (2013) mengatakan dalam bukunya bahwa teori behaviorisme ini menganggap belajar itu sebagai proses yang mengharapkan adanya sebuah pengalaman dan pelatihan, dalam aliran teori ini sebuah pembelajaran atau belajar sebuah bahasa merupakan bentuk perilaku yang didapatkan dalam serangakaian sebuah pengalaman yang telah direkam oleh otak. Aliran ini juga biasanya disebut dengan aliran tabula rasa (Nuryani dan Dona, 2013). Terkait dengan pemerolehan bahasa, tabula rasa ini merupakan istilah untuk menyebutkan bahwa anak yang baru lahir itu bagaikan kertas putih atau kertas kosong yang kemudian dicoret-coret oleh lingkungannya. Maksudnya bahwa pemerolehan bahasa pada anak sangat bergantung dari bahasa-bahasa di lingkungannya, baik lingkungan keluarga, lingkungan sekitas, maupun lingkungan sekolah. Permasalahannya bagaimana pemerolehan bahasa kedua Ahmad, anak keluarga Somalia Umur 4 Tahun dalam Lingkungan Mayoritas Masyarakat Indonesia di Daerah Ciputat Tangerang Selatan. Tujuannya adalah untuk mendeskripsikan sistem pemerolehan bahasa kedua Ahmad dan pola-pola bahasa Ahmad dalam komunikasi kepada orang tua dan peneliti.

\section{METODE}

Dalam penelitian ini menggunakan metode kualitatif dengan menggunakan pendekatan deskriptif. Menurut Denzim dan Lincold (dalam Anggito dan Setiawan, 2018) menyatakan bahawa penelitian yang bertajuk kualitatif adalah penelitain yang menggunakan sebuah latar alamiah dengan maksud menafsirkan sebuah fenomena yang terjadi dan 
dilakukan dengan jalan melibatkan sebuah metode yang telah ada. Selain itu, ada juga yang mengungkapkan, menurut Ericson (dalam Anggito dan Setiawan, 2018) bahwa penelitain kualitatif berusaha untuk menemukan dan menggambarkan penelitian secara naratif dan melakukan kegiatan yang berdampak dari tindakan yang dilakukan terhadap sebuah kehidupan mereka (Anggito dan Setiawan, 2018).

Jadi, dalam penelitain ini menggunakan metode yang telah diungkapkan dalam metode penelitian yang bertujan untuk mengungkapkan fenomena yang terjadi sebagai sumber data yang telah diambil sebagai sampel untuk diteliti dan digambarkan secara naratif serta untuk mendapatkan hasil dalam penelitain ini yang dimana peneliti akan mengungkapan sistem atau cara pemerolehan bahasa kedua, anak Somalia yang masih berumur 4 tahun yang tinggal di Ciputat, Tangerang Selatan.

Data diperoleh dari hasil pertanyaan yang diajukan peneliti dan peneliti berkerja sama dengan ibunya untuk dapat mengajukan pertanyaan yang akan peneliti ajukan. Data yang peneliti peroleh merupakan catatan-catatan pengajuan pertanyaan yang kemudian peneliti akan olah untuk memudahkan dalam penelitian.

Data penelitian ini berupa bahasa Ahmad, anak Somalia yang diajak berdialog peneliti, yang menirukan kalimat-kalimat jawaban. Data tersebut diambil dengan metode simak libat cakap dan metode cakap dengan teknik catat. Data yang telah diklasifikasi dianalisis cengan metode deskriptif analitis.

\section{HASIL DAN PEMBAHASAN}

\section{Sistem Pemerolehan Bahasa Kedua, Ahmad Anak Warga Somalia di Ciputat Timur,} Kabupaten Tangerang Selatan

Dalam penelitian ini objek yang diambil ialah anak seorang warga Somalia yang berumur 4 tahun 8 bulan yang bernama Ahmad. Seorang dari anak tukang cuci pakaian di daerah Jl. Jambu Sari, Ciputat Timur, Tangerang Selatan, Provinsi Banten. Bahasa yang digunakan dalam keseharian oleh kedua orang tuanya ialah bahasa Inggris. Sejak kecil dirinya dikenalkan bahasa pertama dengan bahasa Inggris, tetapi ia juga terkadang menggunakan bahasa Indonesia sebagai bahasa kedua. Hal ini disebabkan oleh faktor lingkungan, sebagai tempat tinggal kedua orang tua Ahmad di Indonesia selama 14 Tahun.

Sejak kecil, Ahmad sangat senang bermain sesama anak seusianya di lingkungan sekitar rumahnya dan ibunya berkerja. Ahmad cukup lancar menggunakan bahasa keduanya yaitu bahasa Indonesia, dan bahasa pertamanya juga sangat lancar karena kedua orang tuanya menggunakan bahasa Inggris sejak Ahmad balita, tetapi tidak jarang juga kedua orang tuanya mengajarkan Ahmad menggunakan bahasa Indonesia. Hal ini dipacu oleh faktor lingkungan tempat mereka tinggal mayoritas masyarakat Indonesia. Lingkungan yang sekarang ia tempati terdapat banyak anak seusia Ahmad yang mayoritas berbahasa Indonesia. Ahmad mempelajari bahasa keduanya, yakni bahasa Indonesia dilakukan secara tidak langsung dalam lingkungannya yang hampir semua anak seusianya berbicara menggunakan bahasa Indonesia. Ketika berinteraksi dengan teman-temannya, Ahmad dapat menggunakan bahasa Indonesia sebagai penyesuaian terhadap lawan bicaranya itu, meskipun terkadang Ahmad melakukan 
campur kode dengan bahasa Inggris ketika ia sedang berinteraksi kepada anak-anak yang seusia dengannya.

Selain faktor lingkungan sekitar, bahasa Indonesia yang didapatkan oleh Ahmad juga berasal dari Ibunya yang terkadang menggunakan bahasa Indonesia dalam interaksi kepada Ahmad. Selain karena lingkungan keluarga, yakni ibunya dan faktor lingkungan sekitar ketika bermain sehari-hari, faktor media juga membantu Ahmad dalam pemerolehan bahasa keduanya, yakni bahasa Indonesia, ketika ibunya sering membuka youtube dan televisi, Ahmad juga ikut menonton apa yang ditonton oleh ibunya, sehingga hal itu dapat meningkatkan mutu pemerolehan bahasa kedua Ahmad seorang anak kebangasaan Somalia yang telah tinggal di Indonesia selama 14 tahun.

Bahasa yang diperoleh oleh Ahmad dapat dikatakan cukup baik karena anak tersebut mampu menguasai bahasa Indonesia meskipun bahasa pertama anak tersebut merupakan bahasa Inggris, tetapi ia dapat berinteraksi dengan baik kepada teman-temanya yang seusia dengannya dan Ahmad dapat menyesuaikan bahasa yang digunakannya dalam berinteraksi dengan lawan bicaranya. Berikut merupakan hasil wawancara peneliti kepada Ahmad dengan mengajukan sedikit pertanyaan yang dapat dimengerti oleh Ahmad.

\title{
Bentuk Pola-pola Berbahasa Ahmad, Anak Warga Negara Somalia
}

Ahmat sebagai anak warga Somalia dapat memahami maksud tuturan peneliti yang menggunakan bahasa Indonesia dengan baik ketika menjawab pertanyaan-pertanyaan peneliti. Ahmad dapat menggunakan dua bahasa sekaligus, yakni bahasa Indonesia dan bahasa Inggris dalam kalimat-kalimat jawabannya. Misalnya:

\author{
Data 01 \\ Peneliti : Hallo Ahmad, apakabar? \\ Ahmad : Iam Fine, kakak gimana kabalnya. \\ Peneliti : Kakak baik, Ahmad lagi ngapain? \\ Ahmad : Playing Video game. \\ Peneliti : Main game apa Ahmad? \\ Ahmad : Playing game kejal-kejalan.
}

Berdasarkan ujaran yang diucapkan oleh Ahmad, dapat dikatakan bahwa Ahmad sangat bagus dan jelas dalam penyampaiannya menggunakan bahasa Indonesia, walaupun Ahmad kadang membalas pertanyaan menggunakan bahasa pertamanya, yaitu bahasa Inggris, tapi sisi positifnya Ahmad dapat mengerti apa yang diucapkan oleh peneliti, padahal peneliti menggunakan bahasa Indonesia. Peneliti sengaja menggunakan secara penuh bahasa Indonesia dalam penelitan pemerolehan bahasa ini, saat peneliti menanyakan kabar Ahmad, ia sontak menjawabnya menggunakan bahasa Inggris dan mencampurnya menggunakan bahasa Indonesia, ktiks peneliti kabarnya Ahmad, sontak Ahmad langsung menjawabnya menggunakan bahasa pertamanya, yaitu bahasa Ingris dan digabungkannya dengan bahasa kedua Ahmad yaitu bahasa Indonesia, terjadi campur kode antara bahasa Inggris dan Bahasa Indonesia. 


\section{Data 02}

Ahmad : Mom, Iam hungry aku mau makan.

Ibunya : Kamu lapar Ahmad?

Peneliti : Ahmad mau makan apa?

Ahmad : Yes Mom, aku mau makan ayam goleng kak.

Berdasarkan ujaran kedua dalam penelitian ini, ujaran yang disampaikan oleh Ahmad dia masih mempadukan antara dua bahasa, masih terdapat campur kode disini, memnag bahasa pertama tidak bisa dipisahkan dalam keseharian seorang anak yang dari lahir telah mendapatkan bahasa pertamanya, tapi faktor lingkungan Ahmad tidak bisa membohongi dia dalam pemerolehan bahasa keduanya, sepertinya Ahmad sangat susah dalam pelafalan huruf //r dalam kata goleng ia mengucapkannya dengan salah, kata yang seharusnya ialah Goreng, hal ini disebabkan karena Ahmad sangat susah melafalkan fonem //r dalam kata goreng, sehingga ia menyebutnya goleng. Dalam percakapan diatas dapat dilihat bahwa ibunya sengaja menggunakan bahasa Indonesia dalam pertanyaan yang diajukan kepada Ahmad, tapi Ahmad tetap menjawabnya dengan bahasa pertama dan kedua, diaman unsur tersebut merupakan campur kode.
Data 03
Peneliti : Ahmad, kamu suka main apa selain main game?
Ahmad : Aku suka main sama temen-temen kak, main kejal-kejalan.
Peneliti : kamu cepet gak larinya?
Ahmad : aku cepet lalinya.
Peneliti : Wah Ahmad hebat yaaah.
Ahmad : (ketawa layaknya anak-anak) hehehhe iya kak.

Berdasarkan ujaran ketiga dalam penelitian ini, ujaran yang diungkapkan oleh Ahmad terdapat kemajuan pesat dalam pemerolehan bahasa keduanya, tampaknya Ahmad akan terbiasa menggunakan bahasa kedunya jika lawan bicaranya itu menggunakan bahasa kedua yang ia gunakan, hal itu terbukti dalam data ketiga yang telah diteliti oleh peneliti, dimana dalam data ketiga ini Ahmad sebagai objek peneliti bahasa kedua, ia sudah tidak menggunakan bahasa Inggris dalam ujarannya, sudah tidak terlihat campur kode dalam ujaran yang ketiga ini, tapi nampaknya ahmad masih merasa kesusahan dalam pengucapan fonem //r pada kata kejal-kejalan yang seharusnya dikatakan sebagai kejar-kejaran.

\section{Data 04 \\ Ahmad : mom, aku mau makan aci oleng. \\ Ibunya : okeey nanti mama masakin ya. \\ Ahmad : oke mom. kakak mau aci oleng juga? \\ Peneliti : ahh gak usah, kakak sudah kenyang.}

Berdasarkan ujaran keempat dalam penelitain ini, ujaran diungkapkan oleh Ahmad terdapat perubahan dari ujaran sebelumnya, dalam ujaran keempat ini, Ahmad menginginkan nasi goreng, tapi dalam pengucapannya fonem //n dan // s hilang, diganti pelafalannya 
menjadi aci, dan dalam ujaran keempat ini, lagi-lagi Ahmad tidak bisa mengucapkan fonem //r, sepertinya memang Ahmad mengalami kesusahn dalam pengucapan fonem //r terbukti dalam pecakapan Ahmad "Kakak mau aci oleng juga?". Dan hilangnya fonem //g pada kata oleng yang sesunguhnya kata itu ialah goreng. Ahmad juga mempunyai sifat yang peduli kepada orang lain, hal itu dapat dibuktikan dalam percakapan yang dimana dia menanyakan saya, apakah saya ini makan juga.

$\begin{array}{ll}\text { Data 05 } & \\ \text { Ahmad } & \text { : Kakak ayo nonton tipi. } \\ \text { Peneliti } & \text { : Ayoo, kamu bisa nyalain nggak? } \\ \text { Ahmad } & \text { :Bisa kakak. } \\ \text { Peneliti } & \text { : Kamu mau nonton apa? } \\ \text { Ahmad } & \text { Mau nonton kaltun. } \\ \text { Peneliti } & \text { :Kartun apa Ahmad? } \\ \text { Ahmad } & \text { :Kaltun yang kembal kakak. }\end{array}$

Berdasarkan ujaran kelima dalam penelitian ini, ujaran diungkapkan oleh Ahmad yang dimana ia bertujuan untuk mengajak peneliti menonton televisi bersamanya, dalam ujaran kelima ini, terlihat kemajuan besar seperti ujaran ketiga, yang dimana Ahmad sama sekali tidak menggunakan bahasa pertamanya yaitu bahasa Inggris, hal ini dapat disimpulkan bahwa Ahmad dapat mennyesuaikan bahasa apa yang digunakannya seseuai lawan tuturnya itu, faktor lingkungan memang sangat berpengaruh dalam pemerolehan bahsasa anak, dalam percakapan diatas, dapat dilihat bahwa pengucapan televisi yang diucapkan oleh Ahmad belum sempurna, ia ,menggunakan fonem /p/ untuk pengucapan kata televisi yang menjadi tipi, dan lagi-lagi dalam ujaran kelima ini, Ahmad tidak dapat melakukan pengucapan fonem /r/, hal ini dapat dilihat dalam percakapan "kaltun yang kembal kakak" yang seharusnya kartun yang kembar kakak.

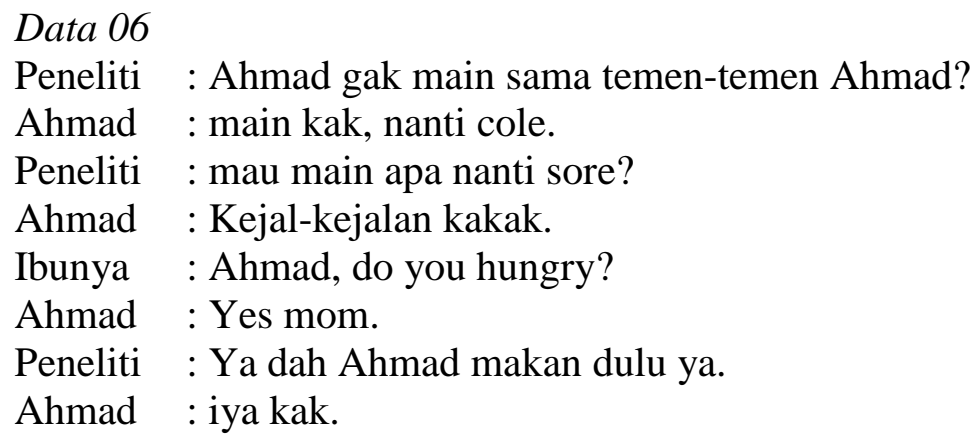

Berdasarkan ujaran keenam dalam penelitian ini, ujaran yang diungkapkan oleh Ibu Ahmad, yang dimana Ibu Ahmad memancing Ahmad dengan menggunakan bahasa Inggris, dan Ahmad membalasnya dengan kata "Yes mom", lagi lagi Ahmad membuktikan bahwa pemerolehan bahasa yang diungkapkan oleh Ahmad tergantung kawan tuturnya, jika kawan tuturnya menggunakan bahasa Inggris, Ahmad akan menggunakan bahasa Inggris, begitu pula sebaliknya, dan terdapat penghilangan fonem /s/ pada kata sore, Ahmad mengungkapkan sore 
dengan kata cole, dan dalam ujaran keenam ini, Ahmad masih tidak bisa menyebutkan fonem $/ \mathrm{r} /$.

Data 07

Peneliti : Ahmad, kakak pulang dulu yaaa.

Ahmad : kakak mau kemana?

Peneliti : kakak pulang dulu yaa Ahmad, nanti ketemu lagi ya

Ahmad : okay, cee you again kak

Peneliti : see you too Ahmad.

Berdasarkan ujaran ketujuh, sekaligus ujaran terakhir dalam penelitian ini, dapat disimpulkan bahawa Ahmad merupakan anak yang dapat menggunakan dua bahasa secara sangai baik, pemerolehan bahasa yang ia dapatkan baik dari ibu maupun lingkungan tempat ia tinggal, membuat Ahmad pandai menggunakan dua bahasa walaupun ia masih berumur 4 tahun, namun layaknya aanak seusia Ahmad, dimana ia masih belum tepat menyampaikan kata perkata dalam bahsa indonesia, berbeda dengan bahasa Inggris, sejauh dalam penelitan ia tidak sedikit melakukan kesalahan dalam penggunaan bahasa inggrisnya, dan kekurangan Ahmad ialah tidak bisa mengucapkan fonem /r/.

Meskipun begitu, pemerolehan kata yang didapatkan oleh Ahmad sudah cukup baik dalam pemerolehan bahasa kedua dalam faktor lingkungan, walaupun dalam tiap kalimat kalimat tertentu, Ahmad belum fasih dalam pengucapan sebagain kata bahasa Indonesia, dann Ahmad tidak bisa mengucapkan kata tertentu dalam bahasa indonesia, Ahamd juga sangat susah mengungkapkan fonem /r/. Hal itu banyak terdapat bukti dalam data penelitan, dan hal itu hampir semua yang ada fonem /r/, Ahmad mengubahnya menggunak fonem /1/.

Pada usia Ahmad yang sudah menginjak 4 tahun 8 bulan ini pemerolehan bahasa pertama dan bahasa kedua yang diperoleh oleh Ahmad sudah dapat dikatakan sangat baik, meskipun ada seikit kesalah kata dalam setiap pelafalan bahasa kedunya yaitu bahasa Indoensia, dan Ahmad masih seidikit kesulitan dalam pengucapannya pada fonem-fonem tertentu, namun hal yang dilakukan oleh Ahmad itu tidak mengurangi makna dari kata yang diucapkannya itu.

Berdasarkan data yang telah diteliti di atas, pengaruh lingkungan mayoritas berpengaruh besar dalam pemerolehan bahasa anak, terutama pemerolehan bahasa kedua, dapat dikatakan pemerolehan bahasa kedua tidak semuanya hal itu dilakukan secara pembelajaran, faktor lingkungan juga berpengaruh besar dalam pemerolehan bahasa anak yang masih berusia 4 tahun ini, selain faktor lingkungan, faktor dukungan orang tua juga sangat berpengaruh dalam proses pemerolehan bahasa kedua anak.

Pengaruh lingkungan ini sangat membantu pemerolehan bahasa anak, apalagi Ahmad merupakan anak dari warga somalia, yang berdomisili di Indonesia dan memounyai bahasa pertama yaitu bahasa Indonesia, apalagi orang tua Ahmad sudah 14 tahun tinggal di Indonesia, orang tua Ahmad juga tidak jarang secara langsung mengajarkan Ahmad bahasa Indoensia, dengan Anak seusia Ahmad, tidak dapat dipungkiri lagi, faktor lingkungan dan faktor orang tua berpengaruh besar terhadap pemerolehan bahasa pertama dan pemerolahan bahasa kedua pada anak. 


\section{SIMPULAN}

Berdasarkan uraian di atas dapat disimpulkan bahwa pemerolehan bahsa Ahmad, anak warga Somalia yang hidup di Indonesia dengan usia 4 tahun 8 bulan yang berbahasa ibu bahasa Inggris, karena pengaruh lingkungan keluarga, lingkungan sekitar, dan karena media sosial youtube dan tayangan di televisi. Lingkungan keluarga Ahmad dapat berkomunikasi dengan dua bahasa, yakni bahasa Inggris dan bahasa Indonesia. Lingkungan sekitar tempat kerja ibunya dan lingkungan sekitar teman sebaya bermain dalam berkomunikasi berbahasa Indonesia. Tayangan film di media sosial youtube dan televisi yang ditonton dan televisi. yang ditonton bersama ibunya, sebuah tayangan film berbahasa Indonesia, Ahmad dapat menangkap dan memahami maksudnya.

Bentuk pola-pola berbahasa Ahmad dalam berkomunikasi melalui tanya jawab dapat berkomunikasi dua bahasa sekaligus atau terjadi campur kode, yakni bahasa Inggris dan bahasa Indonesia. Pola-pola berbahasa Indonesia menunjukkan bahwa Ahmad sudah memiliki pola-pola bahasa Indonesia yang baik dan benar. Secara fonologis, Ahmad masih belum bisa mengucapkan fonem /r/ dalam bahasa Indonesia yang diganti dengan fonem /l/. Dalam pengucapan fonem /s/ diganti dengan fonem /c/. Ahmad sangat memahami maksud pertanyaan peneliti sehingga dapat menjawab pertanyaan dengan baik dan benar. Ahmad mampu menyesuaikan bahasa apa yang digunakan oleh kawan tuturnya itu. Untuk anak seusianya, tentu saja penguasaan dua bahasa menjadi hal yang sangat rumit, tapi hal tersebut tidak berlaku pada Ahmad

\section{DAFTAR PUSTAKA}

Anggito, A. dan Setiawan, J. 2018. Metodologi Penelitian Kualitatif. Sukabumi: CV Jejak.

Berger, C.R. dan Chaffee, S.H. (eds.). 1987. Handbook of Communication Science. Newbury, CA: Sage Publications Inc.

Dardjowidjojo, S. 2003. Psikolingusitik: Pengantar Pemahaman Bahasa Manusia. Jakarta: Yayasan Pustaka Obor Indonesia.

Natsir, N. 2017. "Hubungan Psikolinguistik dalam Pemerolehan dan Pembelajaran Bahasa". Jurnal Retorika, 10 (1).

Nurhadi dan Roekhan. 1990. Dimensi-dimensi dalam Belajar Bahasa Kedua. Bandung: Sinar Baru YA3 Malang.

Nuryani dan Dona, P.K.A. 2013. Psikolinguistik. Ciputat: Mahzab Ciputat.

Oktavia, Y. dan Abdullah, Y. 2017. Komunikasi dalam Perspektif Teori Dan Praktik. Yogyakarta: CV Budi Utama. 